\title{
Analysis of composite endpoints in gene expression studies in oncology
}

\author{
ZA Marhoon ${ }^{*}$, SM Borgan ${ }^{1}$, K Zakeri $^{2}$, LK Mell ${ }^{3}$ \\ From International Conference for Healthcare and Medical Students (ICHAMS) 2013 \\ Dublin, Ireland. 11-12 October 2013
}

\section{Background}

Event-free survival (EFS) endpoints are composite endpoints frequently used in cancer gene expression studies to evaluate the effects of gene expression on patient outcomes. Event free Survival endpoints in oncology, such as Overall survival, typically combine both cancer-specific 'death from cancer' and non-cancer specific events 'death from other causes'. Reporting analysis on each event comprising the composite endpoint is necessary to draw more specific inferences regarding outcomes, especially in the presence of competing risks. The extent to which cancerspecific and non-specific events are separated in contemporary gene expression studies in oncology is unknown.

\section{Methods}

We identified 259 gene expression studies published between June 2007 and January 2012, with analysis of at least one EFS endpoint. We excluded meta-analyses $(\mathrm{n}=14)$, studies in recurrent/metastatic disease $(\mathrm{n}=22$,$) stu-$ dies without EFS endpoints and studies that censored competing events $(n=39)$, studies in foreign languages $(n=4)$, retracted, irrelevant to research topic or unavailable online $(\mathrm{n}=22)$. The remaining 158 studies were independently evaluated by two reviewers according to the extent of reporting on each of the events comprising the EFS endpoint.

\section{Results}

Sixteen studies could not be categorized because endpoints such as EFS were undefined or ambiguously defined. Of the remaining 142 studies, fifteen (10.6\%; 95\% confidence interval (CI), 5.4-16.2\%) reported effects on both cancer and non-cancer events comprising the EFS endpoint. None of these reported any statistical analysis. Forty-Two studies (29.6\%; 95\% CI, 21.1-35.9\%)

${ }^{1}$ Royal College of Surgeons in Bahrain, P.O. Box 15503, Adilya, Bahrain Full list of author information is available at the end of the article reported only the effect on the cancer-specific component of endpoints, but not its complement, with statistical analysis provided in 18 (12.7\%; 95\% CI, 6.8-19.3\%). In eighty-five studies (59\%; 95\% CI, 50.4-69.3\%), no effects on cancer-specific components of the EFS endpoints were given.

\section{Conclusions}

The majority of gene expression studies do not report cancer-specific effects comprising the Event Free Survival endpoints. Increased specificity is required in the design and reporting of cancer gene expression studies.

\section{Authors' details \\ ${ }^{1}$ Royal College of Surgeons in Bahrain, P.O. Box 15503, Adilya, Bahrain. \\ ${ }^{2}$ University of California San Diego, U.S.A. ${ }^{3}$ Department of Radiation \\ Oncology. University of California San Diego, USA.}

Published: 14 January 2015

doi:10.1186/1753-6561-9-S1-A17

Cite this article as: Marhoon et al:: Analysis of composite endpoints in gene expression studies in oncology. BMC Proceedings 2015 9(Suppl 1): A17.

Submit your next manuscript to BioMed Central and take full advantage of:

- Convenient online submission

- Thorough peer review

- No space constraints or color figure charges

- Immediate publication on acceptance

- Inclusion in PubMed, CAS, Scopus and Google Scholar

- Research which is freely available for redistribution 